\title{
The NATIONALITY POLITICS OF 1989 IN THE SOVIET UNION ACCORDING TO THE GORBACHEV FOUNDATION
}

\author{
ARCHIVES \\ TSOTNE TCHANTURIA ${ }^{1}$
}

The developments of the year 1989 played a crucial role in the demise of the Soviet Union. Even though the "European" part of the 1989 events is widely well known to the public, the part of the story from the perspective of the Soviet Union lacks coverage. In the following article, the findings of our study of the Gorbachev Foundation's 1989 archival documents, within the scope of the nationality politics in the Soviet Union, are presented. The review of the chains of events provoked by the Soviet intra-national conflicts will give a reader a better insider understanding of the systemic crisis of the Soviet state.

\section{INTRODUCTION}

The year 1989 had huge significance in world history, the famous consequences of which are all too well know to us. According to the editor of the Gorbachev Foundation's analytical report on the significance of the year 1989, „1989 was the chronological and semantic peak of Gorbachev's Perestroika" [Zdravomislova(ed.), 2010: 6].

In the following article, we would like to present the findings of our study of the Gorbachev Foundation's 1989 archival documents, within the scope of the nationality politics in the Soviet Union. From the excerpts of Politburo meetings, we can understand the crucial significance of the intra-national processes during the late 1980s in the Soviet Union. „Intra-national relations are the most crucial base of our state," mentioned Gorbachev at the CPSU Politburo meeting on 11 June 1987, „if these foundations do not stay standing, everything else will start to crack” [Belyaev(ed.),(7) 2008: 95]. „We should look at every problem in the Soviet Union from the prism of intra-national relations," further noted Gorbachev on 11 April 1988 [Belyaev(ed.),(10) 2009: 229]. In short, nationality, and identity in general, was among the most crucial elements of the Soviet systemic crisis in 1989 that finally caused its formal demise in 1991.

The chronology of events, along with the collected passages from various types of archival documents concerning nationality politics, covers the processes developing at the judicial level (e.g. declarations of state sovereignty and laws on state language by Union Republics, declarations by the Autonomous Republics/Oblasts demanding a higher status of sovereignty from Moscow, resolutions declaring the 1939 German-Soviet Pact lawless, abolition of Article 6 of the

\footnotetext{
${ }^{1}$ Phd student, International Relations Multidisciplinary Doctoral School, Corvinus University of Budapest The present publication is the outcome of the project „From Talent to Young Researcher project aimed at activities supporting the research career model in higher education", identifier EFOP-3.6.3-VEKOP-16-2017-00007 co-supported by the European Union, Hungary and the European Social Fund.
} 
Constitution (on the monopoly of the CPSU), etc.) and at the factual level (e.g. demonstrations demanding independence or a higher status of sovereignty, clashes between different nations and ethnicities provoked by separatist demands, interventions by the Soviet army for normalization of the critical situation, etc.).

During our research, we reviewed six edited volumes of Gorbachev's selected works, including up to 3000 pages of archival documents from the entire period of 1989, and two edited volumes on the chronology of the Gorbachev period. Our scope was narrowed to the nationality politics in the Soviet Union during 1989. The collected passages cover the events taking place in almost every republic of the Soviet Union, except the Kyrghyz and the Tajik Republics. Concerning the Turkmen Republic, only one chronological item was present, notifying that on the festive manifestation of May 1 in Aşgabat, a group of youth organized a protest [Zdravomislova(ed.), 2010]. Most of the passages from the reviewed literature concern developments in the Baltic Republics, Georgia, Azerbaijan, Armenia, Ukraine, Russia and Moldova. Accordingly, our article is comprised of chapters titled by the names of the respective republics, where the processes of crises took place. Due to the fact that in some regions, the processes of the crises were closely interconnected, we have decided to group these interconnected republics in different chapters (e.g. Azerbaijan and Armenia in one chapter, and the Baltic Republics in another).

\section{THE POLITICAL CRISIS IN GENERAL}

At the first Congress of People's Deputies of the Soviet Union (May 30, 1989) Gorbachev defined the three major fields of Perestroika's nationality politics: 1 . The political field (in which the rights of republics and autonomous entities should be expanded); 2. The economic field (which should be reorganized in the form of an above-regulated union of economically self-regulating entities); 3. The spiritual field (in which the diversity of national cultures should be recognized) [Belyaev(ed.),(14)2010]. In his address to the Plenum of the Central Committee of the CPSU (December 25, 1989), Gorbachev mentioned why Perestroika and the democratization process appeared to trigger social discontent in the Soviet Union. „Perestroika created conditions for the growth of national self-awareness and national pride in the peoples of the USSR, whereas the democratization of the society allowed the long-precipitated discontent to appear openly in public. [...] National feeling, as such, is a vital component of every healthily functioning nation, however, in the case of a lack of political culture and emotional intensity, a nationalism infection originates, which itself is a poison for the immune system of any social organism, leading eventually to its destruction" [Loginov(ed.), 2007: 110]. In defence of Perestroika, Gorbachev tried to create a discourse that discredits any kind of nationalist phenomenon - „no one should tolerate nationalist phenomenon in any form - whether local nationalism or chauvinism. These are offensive to human dignity and to any nation" [Belyaev(ed.),(15)2010: 78].

A political monopoly of the CPSU and the doctrine of one-party democracy was one of the cornerstones of the Soviet system. The idea of the abolishment of Article 6 of the Constitution, which legalized the political monopoly of the CPSU, was very popular among the public during the late 1980s. As Gorbachev mentioned at the meeting of the CPSU Politburo (November 19, 1989), ,the idea of abolishing Article 6 is widespread in society, even at the Red Square" [Belyaev(ed.),(16)2010: 403]. On 23 May, Sakharov was one of the first persons to demand the abolishment of Article 6 publicly, at the demonstration on Luzhniki Stadium [Zdravomislova(ed.), 2010]. 
On the other hand, from Moscow's perspective, abolishing the CPSU monopoly seemed impossible by as late as November and December of 1989. Leaving the CPSU is an illusion -remarked Medvedev at a meeting with the members of the Communist Party of Lithuania in Moscow (November 16, 1989). On the Plenum of the Central Committee of the CPSU (December 25, 1989), when discussing the decision of the XX Congress of the Communist Party of Lithuania on secession from the CPSU, Gorbachev stated that the abolishment of Article 6 means open support for the aggravation of the process of demise, and urged the CPSU to condemn this action of the Lithuanian Communist Party without hesitation [Loginov(ed.), 2007].

Even though Perestroika and democratization politics created new freedoms in the repressed society, hard power was still an important tool of the Kremlin for controlling internal processes. "The army is necessary to avoid what happened in Sumgait," mentioned Gorbachev on the first meeting of People's Deputiees (May 25, 1989) [Belyaev(ed.),(14) 2010: 297]. Crime levels were on the rise and it would have been very hard to imagine any other solution to this issue in the Kremlin's repertoire other than hard power. „We should use the KGB more actively for combating the crime. The main stimulator of the crime is apparent impunity," mentioned Gorbachev on 31 July 1989 [Belyaev(ed.),(15) 2010: 379]. However, among the list of cases of hard power exertion by the Kremlin was the 9 April tragic dismantling of the peaceful, however unsanctioned, demonstration in Tbilisi, implemented by the Soviet armed forces, which killed 21 (mostly women and teenagers) and wounded several hundred.

On 16 August, a dialogue between M. Klyamkin and A. Migranyan was published in Literaturnaya Gazeta under the headline - „Is the ,iron hand' necessary?” Here, they presented the idea that the path to democratization in the Soviet Union might first cross through authoritarianism [Loginov(ed.), 2007: 69].

In his formal address to the public from the central television (September 9, 1989), Gorbachev stated that extremely harsh control should be implemented in every city and populated area of the Soviet Union. He called for delegating broader authority to every law enforcement entity, the improvement of their equipment, an increase of the troops in the internal army, and an improvement of the economic conditions of every soldier [Belyaev(ed.),(16) 2010].

Important actors in the ongoing political crisis were the so-called Popular Fronts. They started to appear in the Soviet Union around June 1988, during the preparation period for the XIXth Conference of the CPSU. Social movements in the Baltic Republics had a special role in this context - constituent assemblies of these organizations were held during October of the same year. Later on, the same popular fronts started to appear in other republics and in the cities of the Russian Federation. The main goal of the popular fronts was the recognition of the independence of their respective countries. In parallel to this process, Russian speaking populations around the Soviet Union started to create „interfronts," or alternative organizations to the popular fronts, in order to save the union from dismemberment. Interfronts tried to reach compromises with the popular fronts, however, the latter groups refused to cooperate [Belyaev(ed.),(14) 2010].

The price of the collapse of the Soviet Union was very high, and Gorbachev appeared to be defending Perestroika by talking on the collateral damage that the demise of the Soviet state would bring to its members (as a note, most of these anticipated dangers were realized). During his meeting with the Baltic leadership, Gorbachev highlighted that the Soviet states were so deeply interconnected, that breaking these links would set the whole country back by several decades [Belyaev(ed.),(16) 2010]. Demographic interconnectedness was the number one risk, capable 
of causing an immediate economic shock to the whole economy by creating the huge waves of IDPs/refugees, as far more than 60 million people lived beyond the borders of their national republics in the Soviet Union [Belyaev(ed.),(16) 2010].

Another important aspect of the problem was that there were no real mechanisms to accommodate the secession demands of the Union Republics. Article 72 of the 1977 Soviet Constitution stated: "each Union Republic shall retain the right to freely secede from the USSR.” In relation to this clause, Gorbachev remarked that (April 27, 1989), „about the right to secede from the Soviet Union - there is no mechanism. We lost it somewhere on the road." [ $\operatorname{Loginov}(e d$.$) ,$ 2007: 67].

\section{BALtic Republics}

At the CPSU Politburo meeting, Gorbachev called the Baltic region ,the source of the separatism virus" in the Soviet Union (March 3, 1989). On 18 January 1989, the Estonian SSR was the first of the Baltic Republics to adopt a law on the state status of the native language. Nearly a week later, the Lithuanian Supreme Soviet followed the same path (January 26, 1989), and on May 7, the Latvian. At the 24 January Politburo meeting, Gorbachev mentioned that the Kremlin was ready for experiments (in the Baltic Republics) with the "national economy" and "democracy," but they first needed to invent a mechanism capable of saving the whole union complex from collapse [Belyaev(ed.),(13) 2010]. Later on, the Politburo decided to form a special commission on Baltic affairs, headed by Medvedev. Summarizing their first meeting, Medvedev reported to Gorbachev: „Brazauskas [The First Secretary of the Communist Party of Lithuania] has no real desire to confront even the most radical extremist elements. [...] Chebrikov was very harsh with him, saying - should we use the special measures, comrade Brazauskas? You know that we will not tolerate the separation of the Republic" [Loginov(ed.), 2007: 55].

On 22 February, an address by the Estonian leadership was published in the newspaper „Soviet Estonia", declaring February 24 the day of Estonian independence [Loginov(ed.), 2007].

In Riga, 250,000 people gathered at a demonstration of the Latvian Popular Front on 12 March 1989 [Zdravomislova(ed.), 2010]. Five days later, on 17 March, the Lithuanian Supreme Soviet finally decided to register the political organization "Sajūdis" [Loginov(ed.), 2007], the movement that would become a symbol of the collapse of the Soviet Union.

From the 27 April Politburo meeting stenogram we can trace that the situation in the region was further aggravated. By Gorbachev's words, in the Baltic Republics Russians were denied from buying products in the shops and the visiting wives of Russian military servismen were denied from receiving a registration of residence or a job. As Brazauskas reported to him, 10,000 Lithuanian officers requested their dismissal. In addition, the Latvian Militsia refrained from making order of the nationalist demonstrations. „Estonians demand to raise the flags of every republic in the Kremlin whenever the meeting of the People's Deputies takes place," reported Lukianov to Gorbachev, who replied that the Kremlin would not follow the UN's lead, and that only one Union flag will be raised [Loginov(ed.), 2007: 66].

At the 11 May Politburo meeting, which was primarily dedicated to discussion of the situation in the Baltic Republics, Gorbachev mentioned, that economic problems were also affecting the national character. By his words, the turbulent process of the raising the national self-consciousness of these republics was taking place [Loginov(ed.), 2007]. Intelligentsia was digging 
into the past, which was followed by a process of re-evaluation of the meaning of „sovereignty”, commented Gorbachev. At the same meeting, Brazauskas presented the alarming results of a sociological survey in Vilnius, according to which the Communist Party had 17\% support, whereas Sajūdis had 70\%. Vagris (The First Secretary of the Communist Party of Latvia) suggested the offering of more freedoms to the republics and providing them with more definite information concerning the 1939 German-Soviet Pact. Väljas (The First Secretary of the Communist Party of Estonia) noted that the Estonian communist party had lost its power since the Spring of 1988, after punishing the nationalist activists. Since then, „we lost the Estonian working class," he remarked [Belyaev(ed.),(14) 2010: 518].

The next week (May 18, 1989), the Supreme Soviets of Lithuania and Estonia discussed the 1939 German-Soviet Pact and demanded its declaration as illegal from the moment of signature. The Latvian Supreme Soviet soon joined their demand [Loginov(ed.), 2007]. On the same day, the Lithuanian Supreme Soviet declared the sovereignty of the republic, which was followed by the Latvian SSR on 28 July of the same year [Zdravomislova(ed.), 2010]. The Estonian Supreme Soviet had already declared the sovereignty of the republic in 1988, on 16 November [Loginov(ed.), 2007].

On 8 August, the law of the Latvian SSR was published in the "Soviet Latvia” newspaper, according to which the sovereignty of Latvia was declared with the rights to its own statehood, the free development of the Latvian language, the national culture, and the economy. On 22 August, the findings of the special commission of the Supreme Soviet of Lithuania on the 1939 German-Soviet Pact were published. The commission found these agreements to be illegal, and accordingly, the laws on the Lithuanian membership to the Soviet Union were declared to have no judicial power. These important changes were followed by multiple manifestations, in all the three republics, on the 50th anniversary of the German-Soviet Pact (August 23, 1989) [Zdravomislova(ed.), 2010].

At a Politburo meeting with the Baltic leadership (September 13, 1989), Gorbachev highlighted three main principles essential for the Baltic Republics, and more broadly for the Soviet Union: 1. All problems should be solved only within the frameworks of the federation, without separation; 2. The unity of the CPSU should not be disturbed; 3 . Equality of all nationalities, regardless of their place of residence, should be defended [Belyaev(ed.),(16) 2010]. Regardless of the Kremlin's instructions, the Lithuanian leadership asserted its independence from the CPSU at the party meeting on 20 September, and five days later, the Supreme Soviet of Lithuania declared its 1940 unification with the Soviet Union to be lawless. In turn, the Kremlin granted wider economic rights to the Baltic Republics, alongside Belarus and the Sverdlovsk Oblast of the RSFSR (September 25-28, 1989) [Zdravomislova(ed.), 2010].

At a Politburo meeting on November 9, Gorbachev noted that the Estonian and Latvian representatives had such a feeling, that there could be no other way for them than to leave the Soviet Union. In his speech at the 2nd Session of the Supreme Soviet of the Soviet Union (November 13, 1989), J. Olekas (Member of the Supreme Soviet of the Soviet Union) notified the Soviet about an address from the Lithuanian Supreme Soviet, asking for a review of the law on general military duties, in order to find an alternative service for the Lithuanian youth, who, by conviction of conscience, refuse to serve in the Soviet army [Belyaev(ed.),(16) 2010].

From Medvedev's speech, delivered at the meeting with the members of the Central Committee of the Communist Party of Lithuania (November 16, 1989), we can trace that only the 
Sąūdis had real political power in Lithuania. „Every decision of the party organizations, not to mention the Supreme Soviet, is made in collaboration with Sajūdis. Now it is clear, [...] that this organization is managed by the right-wing nationalists," noted Medvedev [Loginov(ed.), 2007: 101]. As it seems, Sajūdis was controlling the majority of the press in the country - in the same speech, Medvedev mentioned that 120 out of a total of 182 newspapers in Lithuania were under Sajūdis control [Belyaev(ed.),(17) 2010]. The fact that the Lithuanian communist party was losing its influence on the mass media in general is confirmed by Gorbachev's speech to the Plenum of the Central Committee of the CPSU (December 25, 1989) [Loginov(ed.), 2007].

On 7 December, the Supreme Soviet of Lithuania abolished Article 6 of the republican constitution, which was followed by the public announcement of independence from the CPSU at the XXth Congress of the Communist Party of Lithuania (December 19-20, 1989) [Zdravomislova(ed.), 2010].

As O. Zinchenko (the Head of the political department of the Baltic Military District) mentioned at the CPSU Plenum (December 9, 1989), in the Baltic republics, people were erecting monuments in memory of the „Forest Brothers” and the Latvian and Estonian soldiers of the Nazi SS [Belyaev(ed.),(17) 2010].

From Gorbachev's speech at the CPSU Plenum (December 25, 1989) we can see that nine new political organizations were formed in Lithuania - the Social-Democratic and ChristianDemocratic parties being among them. According to Gorbachev, these political entities shared separatist ideas and discredited socialism, the CPSU, the Soviet government and the Soviet armed forces. Gorbachev also mentioned the ongoing process of politicization of the Catholic Church, which was being manipulated by anti-socialist forces [Loginov(ed.), 2007].

It is interesting to see how the negotiation process between the CPSU and the Lithuanian leadership at the decision of the XXth Lithuanian communist party congress (concerning the secession from the CPSU), ended at the Plenum of 25 December. Gorbachev decided to postpone the official condemnation of the Lithuanian decision. „Comrades, Lithuanians will leave and think about how we proceed further in the future. It would not be serious to demand that Brazauskas change his mind right here. Let us postpone the making of a final decision. Let the representatives of the Lithuanian Central Committee travel back to Lithuania, where they can meet local communists and workers. We will discuss this matter and make necessary steps upon their return" [Loginov(ed.), 2007: 114]. Obviously, this was not the tone of the conversation the Kremlin's leaders were having with their subordinates back in 1955, when Khrushchev practically threatened Hungarian leader Imre Nagy's execution during their meeting in Moscow [Békés, 2010]. But still, the subordinated party followed its own way (on 11 March 1990, the Supreme Soviet of Lithuania adopted the Act of the re-establishment of the State of Lithuania) and Moscow still intervened militarily (on 13 January 1991, Soviet army sub-units entered Vilnius and occupied the TV tower by attack; 14 died and more than 500 were wounded) [Loginov(ed.), 2007]. It is interesting to know that on 27 March 2019, the Lithuanian court sentenced Marshal Dmitry Yazov in absentia to 10 years in prison for war crimes and crimes against humanity committed in Vilnius on 13 January 1991. "Another 66 former Soviet military and KGB officials were given sentences of between 4 and 14 years. Only two of them were present in the courtroom," commented the BBC [BBC, 2019]. 


\section{UKRAINE AND BELARUS}

On 11 February, the Ukrainian Popular Front's program was presented at the meeting of the Ukrainian Writers' Union [Zdravomislova(ed.), 2010].

Gorbachev's understanding of Ukrainian nationalism can be traced by looking at the CPSU Politburo meeting minutes (March 3, 1989). According to him, compared to the other parts of the USSR, the nationality question had an absolutely different character in the Slavic states (Ukraine and Belarus), because everything was so deeply connected with Russia. Obviously, the role of the Russian language had been a dominant factor there - by Gorbachev's words, even Ukrainians and Belorussians had no desire to enrol their children in their „own” schools, especially in cities. Gorbachev said that he could see the motivation of Ukrainian and Belorussian writers - unless, „who is going to read their writings in their own language?” [Loginov(ed.), 2007: 58]. According to him, the first thing that comes to „our” mind when we hear the words „Western Ukraine” and „Western Belarus” are the Benders, the „Forest Brothers,” and 1939.

The problem with demanding a review of the internal borders was present in Ukraine as well. According to Chebrikov's réplique at the CPSU Politburo meeting (April 27, 1989), Crimea and Donbass were demanding that Moscow review the internal borders of Ukraine [Belyaev(ed.),(17) 2010]. As it seems, the same situation was present in Kharkov as well - „what happened in Ukraine when they tried to encroach the Russian language? Donbass and Kharkov immediately demanded to leave Ukraine and join Russia" (October 4, 1989) [Loginov(ed.), 2007: 96]. As far as Crimea is concerned, there were interesting conversations at the CPSU Politburo meeting in July of 1987 concerning the resolution of the Crimean problem. Triggered by the Crimean Tatar's demonstrations, the CPSU was discussing different scenarios for the problem resolution. Solomentsev offered to hand Crimea over to Russia, referring to Lenin's Decree on October 18, 1921. „From a historical and political point of view, it would have been fair to return Crimea back to Russia, but Ukraine will not allow us. [...] The return of Crimea back to the RSFSR would crack the Slavic core of the „socialist empire," Gorbachev replied [Loginov(ed.), 2007: 19-20]. Gromyko remarked that he supported leaving this question for resolution to history.

On 6 June, notice of the adoption of the new law concerning the Ukrainian language was published in the Izvestia newspaper. According to it, Ukrainian was declared the state language, whereas Russian would have the status of intranational communication language [Zdravomislova(ed.), 2010].

On 25 August, Crimean Tatars misappropriated the lands of Bakhchysarai Raion of Crimea [Zdravomislova(ed.), 2010]. We should note, however, that this willful act was perhaps not a surprise to the Kremlin. During the meeting at the Presidium of the Supreme Soviet on 5 July 1987, when the issue of Crimean Tatars was discussed, the Presidum agreed to artificially slow down the resettlement of Crimean Tatars to Crimea, as a temporary solution. Yakovlev offered a 15 to 20 year period for the resettlement. In the end, the exact number of years for the resettlement was not pronounced, but Gorbachev instructed the slowing of the resettlement process, and the meanwhile improvement of the living conditions of Crimean Tatars in Uzbekistan [Belyaev(ed.),(7)2008]. It seems that these „slowing down” tactics did not work quite well.

On 8 September, the constituent assembly of the Ukrainian social movement „Rukh” was gathered. Three months later, on December 8, a notice concerning the first pre-election demonstration of Rukh in Kiev was published in the press [Zdravomislova(ed.), 2010]. 


\section{Moldova}

On 12 March, 20,000 demonstrators gathered at an unsanctioned meeting in Chișinău under the motto „down with the government!” The next week, on 19 March, two sanctioned meetings were held in Chișinău where the supporters of independence also took the floor and addressed the crowd. The same separatist slogans were presented at the Moldavian Popular Front meeting in Chișinău on 25 June [Loginov(ed.), 2007]. Adoption of the new law on language on 1 September by the Supreme Soviet of Moldova, which declared Moldavian the state language and lowered the status of Russian to the language of intranational communication, became the trigger of separatism in Moldova. From the end of August until the 25th of September, people were constantly on strike in Tiraspol and other cities in Moldova. Strikers disagreed with the new law on language, saying that it violated the rights of the Russian-speaking population, for whom Moldavian was not the mother tongue [Zdravomislova(ed.), 2010].

\section{RUSSIA}

On 15 April, the first working conference of the Russian Popular Front was held in Moscow. On the next day, the solidarity demonstration with Georgia, organized by the group „Moscow tribune" took place in Moscow. On 23 April, an unsanctioned demonstration under the supervision of The Democratic Union (liberal party, founded on 8 May 1988) took place in Moscow on Pushkin Square - approximately 70 organizers of the demonstration were detained from a total 300. On May 1-2, several demonstrations organized by the interfronts took place in Leningrad (present-day Saint Petersburg), Kuybyshev (present-day Samara), Sverdlovsk (present-day Yekaterinburg), Omsk, Irkutsk, Gorky (present-day Nizhny Novgorod), and Kalinin (present-day Tver). On 21 May, 100,000 people gathered at the Luzhniki Stadium in Moscow, where Yeltsin, Sakharov, and other leaders addressed the crowd. The same gathering was held at the stadium two days later, where Sakharov demanded the abolishment of Article 6 and the introduction of a multi-party political system. The Constituent Assembly of the Leningrad Popular Front took place on 17 June [Zdravomislova(ed.), 2010].

From the CPSU Politburo meeting (September 8, 1989) stenogram we can trace that some members of the Russian Federation too, had separatist demands. „Tatarstan, Bashkortostan, and Yakutia are demanding the status of Union Republics," noted Gorbachev, ,some members are asking for the creation of new autonomous formations, e.g. Ingushetia." [Loginov(ed.), 2007: 90]. It is interesting to note that the first nationality-based incident during the Gorbachev period took place in Yakutsk (the capital of the Yakutian ASSR) as early as March-April 1986. Here, Russian and Yakutian students of the Yakutsk State University confronted each other. The situation had such a critical character that the Secretariat of the Central Committee of the CPSU released a decree „concerning some negative manifestations among the youth of Yakutsk" in early May. The separatist demands of the Tatarstan and Bashkortostan ASSRs were present since as early as May 1987 [Loginov(ed.), 2007].

The Russian writer Valentin Rasputin, in his article „intelligentsia and patriotism” (1991), mentioned that as far as nearly all Soviet republics are multi-national and multi-religious, the processes of demise might turn all the republics into a Lebanon very easily. „Russia is facing the same threat”, he mentioned, „the processes of demise will proliferate like cholera throughout entire Russia, from the South to the North, from the Volga basin to Siberia" [Loginov(ed.), 2007: 76]. 
On 21 October, the Popular Front of RSFSR was created in Yaroslavl, at a conference of the representatives of Russian popular fronts and democratic movements [Zdravomislova(ed.), 2010].

\section{GEORgIA}

On 18 March, the Lykhny Meeting was held in Lykhny, in the Abkhazian ASSR. Demonstrators, among which the members of the Buro of the Oblast Committee of the CPSU were present, demanded the status of Union Republic for the Abkhazian ASSR. The memorandum was signed by Adleiba (the First Secretary of the Oblast Committee of the CPSU in the Abkhazian ASSR). In his phone call to Medvedev on March 24, Patiashvili (the First Secretary of the Georgian Communist Party) described his anxiety concerning the harsh reaction of the Georgian population to the Abkhaz separatist demands. On 3 April, the working meeting of the CPSU Politburo concerning the Georgian-Abkhaz question was held. Lukyanov considered that the main source of the tensions was the Georgian extremists, like Gamsakhurdia and Kostava, and their chauvinist positions. Medvedev noted that the proposal for granting Union Republic status to the Abkhazian ASSR was unacceptable, however, according to him, Georgian nationalists should be more sternly dealt with [Loginov(ed.), 2007].

From April 4, unsanctioned demonstrations in front of today's Parliament building, organized by informal Georgian associations, were held in Tbilisi on a daily basis. The demands were „Georgian independence!” and „Down with the Russian empire!” The situation became so tense that on April 7, the Buro of the Georgian Communist Party asked the Central Committee of the CPSU to implement a curfew in Tbilisi as needed. Later on, the working meeting of the CPSU Politburo, under the chairmanship of Ligachev, took place in Moscow, deciding to look for political methods of settlement. The meeting decided, however, to send military units to guard the public institutions in Tbilisi without introducing the curfew. At the late evening emergency meeting of the CPSU Politburo members, with Gorbachev and Shevardnadze, at the Moscow airport on 7 April (upon their arrival from London), Gorbachev instructed Shevardnadze and Razumovsky to travel to Tbilisi and to clarify the situation on the spot. The next day, Patiashvili reported to the Kremlin that the situation was being normalized in Tbilisi and there was no need for a curfew. He additionally asked that Shevardnadze and Razumovsky not be sent to Tbilisi, assuming that their arrival would aggravate the situation.

The next piece of information about the Tbilisi developments from the reviewed material is the notice of the 9th of April main incident, according to which during the dismantling operation of the unsanctioned demonstration, implemented by the army, 16 people died and multiple were wounded in Tbilisi on the early morning of April 9. The next day, a curfew was implemented. Patiashvili and several of his associates stepped down from their held positions on 14 April [Loginov(ed.), 2007].

According to Gorbachev, one of the main reasons for the escalation of the April developments in Tbilisi, besides the Georgian extremists and their disorienting demands, was the Georgian Communist Party leadership. „They were supposed to go to the crowd and talk with them, and as it appeared, they were sitting in a bunker," remarked Gorbachev at the CPSU Politburo meeting on 20 April. He found it very problematic that the Georgian Communist Party was unable to reach a compromise with the Georgian intelligentsia, which was in the end what escalated into the tragic events. With this comment, Gorbachev recognized that the Georgian intelligentsia was also a driving force of the demonstrations. „The Georgian intelligentsia is deeply connected with 
the public. It is the bearer of the national symbol, he mentioned, „everything there - the theatre, cinema and music - contains very strong national elements" [Loginov(ed.), 2007: 64].

Another part of the story includes the complaints from Politburo members, including Gorbachev, for not having correct and timely information concerning the tragic developments in Tbilisi and the events preceding it. „Perhaps it would have been a good idea if we had sent someone from the KGB there for the correct information," said Gorbachev at the CPSU Politburo meeting on 20 April [Loginov(ed.), 2007: 64]. At the same meeting, Ryzhkov complained that due to miscoordination, none of the Politburo members had information concerning the Tbilisi developments. „The army intervenes and the General Secretary finds out about it only the next day. Wherever you look, all the business is done without the Politburo's knowing," commented Ryzhkov. The minutes of the meeting finish with a réplique from Gorbachev to Yazov (The Soviet Minister of Defence), „Dimirtyi Timofeevich, from now on, the army should not take part in these kinds of affairs without the Politburo's permission" [Loginov(ed.), 2007: 65].

On 29 June, the Georgian Popular Front was created [Loginov(ed.), 2007]. Two weeks later, clashes between Georgians and Abkhazians took place in Sokhumi, leaving 12 people dead. On 25 August, the First Congress of the Mountain Peoples of the Caucasus was held in Sokhumi and the Confederation of Mountain Peoples of the Caucasus was established. On 19 November, the Georgian Supreme Soviet adopted an amendment of the constitution, according to which the right of „veto" on the Union laws and the right to freely secede from the Soviet Union was confirmed. The amendment also declared all natural resources on the republic's territory to be the property of Georgia. Since 23 November, clashes between Georgians and Ossetians have proliferated [Zdravomislova(ed.), 2010].

\section{Azerbaijan and Armenia}

On 12 January, the Presidium of the Supreme Soviet of the Soviet Union introduced a special form of governance of the Nagorno-Karabakh Autonomous Oblast (Azerbaijan SSR), granting the Kremlin the exclusive right to control the region [Loginov(ed.), 2007]. The special form of governance was present until as late as 28 November of the same year [Zdravomislova(ed.), 2010]. By early May, the situation had become tense in the region - part of the Armenian population expressed mistrust in the special form of governance, demanding the restoration of the local government and the de-facto abolition of Baku's official control on the autonomous oblast [Loginov(ed.), 2007]. On 3 May, a campaign of strikes started in Nagorno-Karabakh and Armenia. By the end of the month, Armenia declared state sovereignty (May 28, 1989). On the next day, the Supreme Soviet of the Armenian SSR adopted the resolution, declaring 28 May 1918 the day of the re-establishment of Armenian statehood [Zdravomislova(ed.), 2010]. 27 June is marked with a demonstration of several-thousand people in Yerevan, demanding that the Congress of People's Deputies of the Soviet Union recognize the right of Nagorno-Karabakh for self-determination [Loginov(ed.), 2007].

Azerbaijan started a blockade of Nagorko-Karabakh in August, which lasted until 25 September of the same year [Zdravomislova(ed.), 2010]. As was stated by Z. Balyan (People's Deputy of the Soviet Union), B. Oliynyk (People's Deputy of the Soviet Union) noted on August 3 the threat of civil war in Nagorno-Karabakh [Belyaev(ed.),(16) 2010]. On 23 September, the Supreme Soviet of Azerbaijan adopted the law on the sovereignty of the Republic [Zdravomislova(ed.), 2010]. 
What we can trace from the stenogram of the Second Session of the Supreme Soviet of the Soviet Union (September 25, 1989) is that Azerbaijan was keeping Armenia under blockade as well. „We are delivering products to Armenia from only one route (Sadakhlo route [through Georgia]), instead of the total three, which is good enough to supply only $1 / 3$ of the whole Armenian population," commented L. Voronin (the First Deputy Chairman of the Council of Ministers of the Soviet Union) (October 3, 1989). According to him, a special airlift to Armenia was organized for product deliveries. We can understand from a report by N. Konarev (The Soviet Minister of Railways), that the population of Azerbaijan was blocking the railroads to Armenia. "People just need a couple of hours to block the railroad," he commented, „women and children lay on the railways” [Belyaev(ed.),(16) 2010: 497]. Concerning this situation, M. Lauristin (Estonian People's Deputy of the Soviet Union) demanded the qualification of the railway blockades as an act of terrorism. The Supreme Soviet eventually decided (October 3, 1989), to instruct the Interior Ministry, the Defense Ministry, and the Ministry of Railways to restore the functioning of the railways [Belyaev(ed.),(16) 2010]. Nevertheless, the blockade was resumed in early December. As was noted by S. Ambartsumian (the People's Deputy of the Soviet Union) on 12 December 1989, the railways and highways directed to Armenia had been blocked from December 4 to December 11 [Belyaev(ed.),(17) 2010].

On 28 November, the Supreme Soviet of the Soviet Union ended the special governing regime of Nagorno-Karabakh and returned governing authority to the Oblast Soviet of the region. On 1 December, the Armenian Supreme Soviet reacted with the adoption of a resolution designating Nagorno-Karabakh as part of Armenia. In response, on 7 December, the Supreme Soviet of Azerbaijan declared the December 1 resolution of the Armenian Supreme Soviet to be an infringement on Azerbaijan's territorial integrity. On 31 December, insurgency broke out in the Nakhichevan ASSR of Azerbaijan and hundreds of kilometres of the Soviet-Iranian border was destroyed [Zdravomislova(ed.), 2010] - according to the Radio Free Europe, Soviet Azerbaijanis rioted along the Iranian border, destroyed checkpoints, by crossing into Iranian provinces with Azeri majorities [Radio Free Europe, 2009]. Interestingly, the Nakhichevan ASSR was the first territorial entity to declare independence in the Soviet Union (on 19 January 1990) [Loginov(ed.), 2007].

\section{UZBEKISTAN}

On 23-24 May, insurgency on the basis of nationality broke out in the Fergana region of Uzbekistan [Loginov(ed.), 2007]. There were clashes between the Uzbek and the Meskhetian Turk youth. On 3 June, the situation was further aggravated by the local Uzbek population, demanding that the Meskhetian Turk citizens leave the country. The Meskhetian Turk minority had arrived on the territory of Uzbekistan as a result of the Stalinist purges of the 1940s. They had been deported from the territory of the Georgian SSR, accused of taking the enemy side during the war. As a result of the Fergana pogrom, according to information from the Communist Party of Uzbekistan, 100 people died, more than 1000 were wounded, 757 houses were burned down, and 27 public buildings and 275 automobiles were destroyed. On 4 June, the Supreme Soviet of Uzbekistan implemented a curfew in the region. As a result, sub-divisions of the internal army of the Soviet Interior Ministry emerged in the region. As was mentioned by Gorbachev at the Congress of People's Deputees (June 7, 1989), law enforcement representatives were using firearms to re-establish control. On 13 to 15 June, Ryzhkov and Chebrikov visited the republic. 
On 15 June, Ryzhkov delivered a speech at the party meeting in Tashkent, offering temporary residence to the Meskhetian Turks of the Fergana region in the RSFSR [Belyaev(ed.),(16) 2010: 497]. On 26 June, the resolution of the Supreme Soviet of the Soviet Union followed, confirming the implementation of Ryzhkov's promises [Loginov(ed.), 2007]. We should note that in parallel to these events, a public demonstration was organized in the Meskheti region of the Georgian SSR, where people demanded that the Meskhetian Turks not be sent back to Georgia.

\section{KAZAKHSTAN}

On 16 June, clashes between the youth of Kazakh and North Caucasian origins (mainly Ingush and Chechen) took place on the dance floor in the city of Novi Uzen (Guryevsk Oblast, Kazakstan SSR). The situation became so critical that on 19 June, a curfew was implemented in the city. A considerable role in the normalization of the situation was played by an initiative group composed of citizens with North Caucasian origins who had initiated the formation of a bilateral committee, together with Kazakhs, in order to work on a resolution of this issue. The committee eventually concluded that the main reasons for the youth clashes in Novi Uzen were not as much their national or ethnic differences, but unfair economic conditions and unemployment. A special governmental commission was also formed in the Kazakstan SSR concerning this issue. At the meeting with the intelligentsia in Almaty in June, Nazarbayev severely criticized the local authorities of the Novi Uzen city and on 24 June, several of them were dismissed from their jobs. As was noted by Medvedev, Nazarbayev apologised to Ingush and Chechen people at the CPSU Plenum on 19-20 September 1989 [Belyaev(ed.),(16) 2010].

\section{Conclusion}

After reviewing and discussing multiple selected passages from Soviet archival documents concerning nationality politics and the political crisis in the Soviet Union, we can see that the processes of the union's demise seemed irreversible in 1989. This was due to the policy of Glasnost that allowed the long-repressed public to express their discontent freely. Gorbachev obviously got it right, that the systemic reformation of the Soviet Union was vitally important, and he was likely expecting some serious turbulence in society as well, but still, as we see it, he underestimated the damaging effect of unleashing of the freedom of the expression power.

Why do modern authoritarian regimes take very seriously the need to gain control of mass media? Could it be that they learned a nice lesson from Glasnost politics? We cannot generalize, but as far as the modern Russian Federation and some post-Soviet states are concerned, who apart from the autoritarianism have a poor welfare system, we can see that control of the mass media, and of the freedom of expression in general, is the existential matter there for the political elites - people given the freedom of expression are more likely to convey their discontent, and if the local media is given the freedom to report on the issue, then there is a big chance that the legitimacy of the political elite will come under question.

What kinds of processes might take place in modern Russia, under the conditions of the application of the Gorbachevist democratization policies, considering the fact that three decades ago, several autonomous entities (like Tatarstan, Bashkortostan, and Yakutia) were demanding separation? Could we claim that, since then, the level of political sovereignty and the social and 
economic conditions in these regions have increased so significantly that if given of freedom of choice, they would not demand separation from Moscow? This is not clear, but what we can clearly see is that the basis for a separatist explosion is there, and the general trend of disintegration in the post-Soviet region makes the chances of this kind of explosion more probable.

Another important observation from the reviewed material concerns Ukraine. As we have seen it, the patterns of today's crisis in Ukraine were already developing at the end of the 1980s. The demographic interconnectedness of the people with Russian and Ukrainian origins appeared to cause a major problem for the territorial integrity of an independent Ukraine. The demands for separation in Donbass and Kharkov started back in 1989 on the basis of the language reform. As far as the case of Crimea is concerned, as was shown, the leadership in the Kremlin had considered the return of the territory to Russia a logical and politically and historically fair decision, as early as in July of 1987. The circumstances, though, which hampered the execution of this scenario, included the risk of exacerbating public discontent and potentially cracking the Slavic core of the „socialist empire.” However, once these circumstances disappeared or lost their significance, Moscow changed its politics.

\section{REFERENCES}

BBC (2019): Lithuania convicts Russians of war crimes under Soviet rule. https://www.bbc.com/ news/world-europe-47725239. Accessed: 2019. 04.12

Békés, C. (2010): „East Central Europe, 1953-1956” in: Leffler, M.P and Westad O.A. (eds.): The Cambridge History of the Cold War. Cambridge University Press, Cambridge

Горбачев М.С. (2008): Собрание сочинений. Том 7. Май - октябрь 1987. Весь Мир, Москва [Gorbachev M. S. (2008): Collected works. Vol. 7. May - October 1987. Ves Mir, Moscow]

Горбачев М.С. (2009): Собрание сочинений. Том 10. Март - май 1988. Весь Мир, Москва [Gorbachev M. S. (2009): Collected works. Vol. 10. March-May 1988. Ves Mir, Moscow]

Горбачев М.С. (2009): Собрание сочинений. Том 13. Декабрь 1988 - март 1989. Весь Мир, Москва [Gorbachev M. S. (2009): Collected works. Vol. 13. December 1988 - March 1989. Ves Mir, Moscow]

Горбачев М.С. (2010): Собрание сочинений. Том 14. Апрель - июнь 1989. Весь Мир, Москва

[Gorbachev M. S. (2010): Collected works. Vol. 14. April - June 1989. Ves Mir, Moscow]

Горбачев М.С. (2010): Собрание сочинений. Том 15. Апрель - июнь 1989. Весь Мир, Москва

[Gorbachev M. S. (2010): Collected works. Vol. 15. April - June 1989. Ves Mir, Moscow]

Горбачев М.С. (2010): Собрание сочинений. Том 16. Сентябрь-ноябрь 1989. Весь Мир, Москва [Gorbachev M. S. (2010): Collected works. Vol. 16. September - November 1989. Ves Mir, Moscow]

Горбачев М.С. (2010): Собрание сочинений. Том 17. Ноябрь-декабрь 1989. Весь Мир, Москва [Gorbachev M. S. (2010): Collected works. Vol. 17. November-December 1989. Ves Mir, Moscow]

Горбачев М.С. (2010): Собрание сочинений. Том 18. Декабрь 1989 - март 1990, стр. 192. Весь Мир, Москва [Gorbachev M. S. (2010): Collected works. Vol. 18. December 1989March 1990. Ves Mir, Moscow]

Логинов В.Т. (ред.) (2007): Союз можно было сохранить. Белая книга: документы и факты о политике М.С. Горбачева по реформированию и сохранению многонационального 
государства. АСТ, Москва [Loginov V. T. (ed.) (2007): The Union could be saved. White Book: documents and facts about the policy of M.S. Gorbachev on reforming and preserving the multinational state. AST, Moscow]

Radio Free Europe - Radio Liberty (2009): Breaking Down The Azerbaijani-Iranian Border. https://www.rferl.org/a/Breaking_Down_The_AzerbaijaniIranian_Border/1916891.html Accessed: 2019.05.29

Здравомыслова О.М. (ред.) (2010): Горбачевские чтения. Вып. 7. 1989 год в российской и мировой истории / Первый съезд народных депутатов СССР: 20 лет спустя / 1989-2009: пути Европы. Горбачев-Фонд, Москва [Zrdavomislova O. M. (ed.) (2010): Gorbachev's reading. Issue 7. 1989 in the Russian and world history / The First Congress of People's Deputies of the USSR: 20 years later / 1989-2009: the paths of Europe. Gorbachev Foundation, Moscow] 